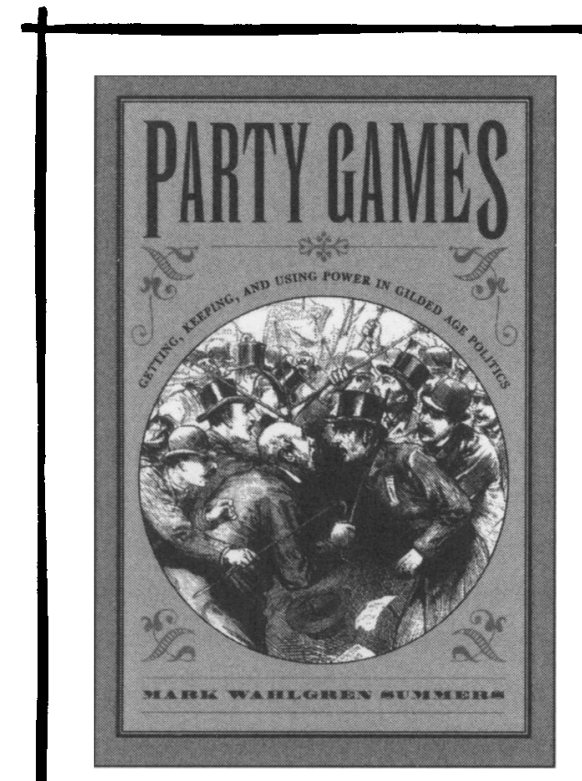

\section{Party Games}

Getting, Keeping, and Using Power in Gilded Age Politics

\section{MARK WAHLGREN SUMMERS}

Cigars, kazoos, and electoral shenanigans.

"In page-turning prose, Summers shows the ways in which the people who made politics their business developed methods to keep themselves in power, deflect dissident thirdparty movements, and accommodate demands enough to disarm those who asked for them. This is an exciting and significant book, certain to take its place as a key work to understanding Gilded Age politics."

- R. Hal Williams, Southern Methodist University

368 pp. \$59.95 cloth / \$22.50 paper

\section{Sounds of Reform}

Progressivism and Music in Chicago,

1873-1935

\section{DEREK VAILLANT}

“Principal characters-musicians, reformers, immigrant and African American Chicagoans seeking pleasure and power-come across as complex human beings. ... A major contribution to our understanding of the ambiguous legacy of progressivism and the meaning of cultural conflict in 2oth-century America."

-Frank Couvares, Amherst College 416 pp., 24 illus. \$59.95 cloth / \$19.95 paper

\section{Music and the Making} of a New South

\section{GAVIN JAMES CAMPBELL}

"An inspired and original work, bringing together ... opera, African American concert singing, and old-time fiddling ... to study conflicts and [the] desires to smooth over those conflicts in the quintessential New South city of Atlanta."

-Ted Ownby, author of American Dreams in Mississippi

240 pp., 23 illus.

$\$ 55.00$ cloth / \$19.95 paper

\section{The Politics of American Religious Identity \\ The Seating of Senator Reed Smoot, Mormon Apostle}

\section{KATHLEEN FLAKE}

"Outstanding."-Publishers Weekly, starred review

“Dazzling. ... A significant contribution to Mormon studies, as well as to American religious and political history by explaining for the first time the reconciliation of the Mormon church and the broader political culture in the early zoth century." - Sarah Barringer Gordon, author of The Mormon Question 256 pp., 32 illus.

$\$ 49.95$ cloth / \$18.95 paper

\section{Marion Butler and American Populism}

\section{JAMES L. HUNT}

"[An] interesting new study of a gifted but nearly forgotten American politician." -Washington Post Book World

"An important contribution to our understanding of American politics in the Populist-Progressive era."

-Robert C. McMath Jr., Georgia Institute of Technology

360 pp. \$49.95 cloth

\section{THE UNIVERSITY OF} NORTH CAROLINA PRESS at bookstores or 800-848-6224 www.uncpress.unc.edu 


\section{Subscribe to the Journal of the Gilded Age and Progressive Era}

For individual subscriptions, which include membership in the Society for Historians of the Gilded Age and Progressive Era: send subscriptions at the rate of $\$ 40$ per year, $\$ 15$ per year student or $\$ 50$ per year joint membership. Students, please provide evidence of enrollment.

Name:

Institution:

Street Address:

City, State, Zip Code:

email address:

For institutional subscriptions: send subscriptions at the rate of $\$ 80$ per year.

Attention:

Institutional name:

Street Address:

City, State, Zip Code:

Daytime Phone:

For international mailing, including Canada and Mexico, add $\$ 5$ The total cost of this order is $\$$

Make checks payable to: Society for Historians of the Gilded Age and Progressive Era

and send to:

Murney Gerlach, SHGAPE Secretary Treasurer

Rutherford B. Hayes Presidential Center

Spiegel Grove

Fremont, $\mathrm{OH} 43420$ 


\section{Sponsoring Organizations and Officers}

Society for Historians of the

Gilded Age and Progressive Era

President

Donna Gabaccia

University of Pittsburgh

Vice-President/President-Elect

Peter Argersinger

Southern Illinois University

Secretary/Treasurer

Murney Gerlach

Rutherford B. Hayes Presidential

Center

\section{Past Presidents}

Michael Les Benedict

Ohio State University

Charles W. Calhoun

East Carolina University

Ballard Campbell

Northeastern University

Robert Cherny

San Francisco State University

Roger Daniels

University of Cincinnati

Leslie H. Fishel, Jr.

Ex-Director, Hayes Center

Walter Nugent

Professor Emeritus, Notre Dame

University

Elisabeth Israels Perry

St. Louis University

Kathryn Kish Sklar

SUNY Binghamton

\section{SHGAPE Council}

Lloyd Ambrosius

University of Nebraska

Ellen Litwicki

SUNY Fredonia

Kimberley Phillips

William and Mary

John Buenker

University of Wisconsin-Parkside

Kristin Hoganson

University of Illinois

Thomas Winter

Bilkent University, Turkey

Roger Bridges

Bloomington, Illinois

Karen Cox

UNC, Charlotte

Daniel Letwin

Penasylvania State University

Shannon L. Parsley

American University (Graduate Student Member)

Newsletter Editor

David Blanke

Texas A \& M University, Corpus Christi

\section{Rutherford B. Hayes Presidential Center}

Murney Gerlach

Executive Director

Illinois State University

Roberta S. Trites

Interim Dean, College of Arts \& Sciences

The Journal of the Gilded Age and Progressive Era is printed for the Society for Historians of the Gilded Age and Progressive Era by Western Newspaper Publishing Co., Inc., 537 E. Ohio Street, Indianapolis, IN 46204 
